\title{
TRANSNATIONAL DIALOGUE ON LANGUAGE EDUCATION IN CANADA AND BRAZIL: HOW DO WE MOVE FORWARD IN THE FACE OF NEOCONSERVATIVE/NEOLIBERAL TIMES?
}

\section{DIÁLOGO TRANSNACIONAL SOBRE EDUCAÇÃO LINGUIISTICA NO CANADÁ E NO BRASIL: COMO PROSSEGUIMOS FACE A TEMPOS NEOCONSERVADORES E NEOLIBERAIS?}

\author{
Daniel de Mello Ferraz* \\ Interview: Prof. Dr. Brian Morgan \\ (York University)
}

\begin{abstract}
This interview with Prof. Dr. Brian Morgan from York University presents some of Dr. Morgan and Dr. Ferraz's perspectives in relation to language education in Canada and Brazil. The conversation plunges into essential topics to be problematized by language educators from both countries: neoconservative politics, neoliberalism, plurilingualism, philosophy of language (Derrida, Bakhtin, Foucault, Deleuze), cultural studies, teacher education, teaching practices. Brian Morgan invites us to go through a process of further thinking in terms of: 1 . The Neoliberal agenda within educational policies and actions, 2 . The relationship between theories (philosophies of language, cultural studies) and practices (how such theories impact - or not - public teachers' pedagogical practices), 3. The design of pedagogical projects (e.g., the Get Involved Project, MONTE MOR; MORGAN, 2014) that provide critical spaces for working within and against neoliberal agendas.

Keywords: language education; Brazil, Canada; neoliberalism; neoconservative times.
\end{abstract}

\section{RESUMO}

Esta entrevista com o Prof. Dr. Brian Morgan da Universidade de York apresenta as perspectivas dos professores Morgan e Ferraz em relação à educação linguística no Canadá e no Brasil. A conversa focaliza temas essenciais para a educação linguística em ambos os contextos: políticas neoconservadoras, neoliberalismo, filosofia da linguagem (Derrida, Bakhtin Foucault, Deleuze), estudos culturais, formação de professores e práticas de ensino. Brian Morgan nos convida a repensar: 1. A agenda neoliberal nas ações e políticas educacionais; 2. As relações entre teorias (filosofias da linguagem, estudos culturais) e práticas (por exemplo, como tais teorias impactam ou não as práticas pedagógicas dos

\footnotetext{
* Universidade de São Paulo (USP), São Paulo, SP, Brasil. danielfe@usp.br 
professores da escola pública); 3. O desenho de práticas pedagógicas (por exemplo, o projeto Get Involved, MONTE MÓR, MORGAN, 2014) que proveem momentos críticos para se trabalhar com e contra as agendas neoliberais.

Palavras-chave: educaçãolinguística; Brasil; Canadá; neoliberalismo; tempos neoconservadores.

\section{INTRODUCTION}

If one considers the context which we Brazilians have faced - after the result of the 2018 presidential elections - in relation to education, higher education, and language education in the country, this interview with Professor Dr. Brian Morgan from York University could not have been made in a more proper time. Professor Morgan has contributed to the Brazilian Projeto Nacional de Novos Letramentos (USP, 2009-2019) for approximately ten years. In this interview, he invites us to go through a process of further thinking in terms of: 1 . A transnational dialogue regarding neoliberal agendas within educational policies and actions, 2. The relationship between theories (philosophies of language, cultural studies) and practices (how such theories impact - or not - public teachers' pedagogical practices), 3 . The design of pedagogical projects (e.g., the Get Involved Project, a service-learning/ volunteering assignment that encourages second/additional language learners to be critical ethnographers) for illiberal and post-democratic times, in which a productive ambiguity within assignment design might provide space for critical work.

Neoliberalism. Neoconservative times. Neoliberal education. Neoliberal agendas. The Right. These are contemporary keywords for every language educator who wishes to problematize language as social practice (as put forward by practically every literacies movement). Class issues, for example, cannot be ignored in a country worldly-known for social inequality and disenfranchisement such as Brazil. In accordance with Apple (2004, p. 13), we argue that "we need to make closer connections between our theoretical and critical discourses on the one hand and the real transformations that are currently shifting educational policies and practices in fundamentally rightist directions on the other hand". It is relevant to point out that Apple's claims date back to 2004, but after 15 years, they are more appropriate than ever:

Today is no different than in the past. A "new" set of compromises, a new alliance and new power bloc has been formed that has increasing influence in education and all things social. This power bloc combines multiple fractions of capital who are committed to neo-liberal marketized solutions to educational problems, neo-conservative intellectuals who want a "return" to higher standards and a "common culture," authoritarian populist religious conservatives who are deeply worried about secularity and the preservation of their own traditions, and particular fractions of the professionally oriented new middle class who are committed to the ideology 
and techniques of accountability, measurement, and "management." Although there are clear tensions and conflicts within this alliance, in general its overall aims are in providing the educational conditions believed necessary both for increasing international competitiveness, profit, and discipline and for returning us to a romanticized past of the "ideal" home, family, and school (Apple, 1996, 2000, 2001a; Apple et al., 2003). (APPLE, 2004, p. 15).

Thus, Dr. Morgan invites us to problematize not only the need to think through neoliberalism contextually (Neo to what? Neo to whom?), but also to envision possibilities of how to include - or not - such discussions in our classrooms, by asking many problematizing questions: "What do these terms mean? How can we make them accessible for a particular audience? How can we make them relevant in our lives? How do they relate to our own practices in our universities and teaching? I mean that's the key: Can we make theory lived? How is it embodied in our world and in our lives? And that's the key challenge. How do we make these ideas relevant to our domains of activity? The potential domains of activity and our opportunities to be agents and change things? So the question then is: What are the possibilities to act under these new kinds of repressive regimes? In the context of this special journal issue, another key point relates to the value of transnational dialogue in exploring the questions just posed" (MORGAN, 2019, this interview).

Towards the end of the interview, Brian questions the colonial language/education perspectives usually bestowed upon us (they - from the Global North - teach us - from the South!) by humbly telling us how much he has learned with these years of transnational knowledge exchange between both countries: "I've always found that working with Brazilians or working on these projects (because you mentioned that there are 30 universities out of a 1000 doing critical literacy work) that there were so many things that made me reflect about things that I don't think about or never recognized in my own local language teaching. The critical imperative that I saw amongst all the people in Brazil was interesting and something comparatively lacking in Canada." To end, I should not only thank professor Morgan for allowing me to interview him, but also invite the reader to explore this "cool" conversation I had with him. This is why I made an effort to purposely transcribe and keep many of the cool-language-interaction we had during this recorded interview in Toronto, Canada, 2019. 


\section{INTERVIEW WITH BRIAN MORGAN}

\section{Brian Morgan and Brazil}

DF: Prof. Morgan, in order to contextualize this interview for Brazilian readers, could you tell us about the transnational academic projects you have developed in partnership with Brazilian academics? In particular, what are the methodological strategies you have developed in this work (i.e. duo-ethnography)?

BM: So, the context. It is always interesting to think about the questions: How did I end up in Brazil? What was the connection? And I think it was Lynn Mario. He and I were supposed to be on a panel in 2006, at the AILA / AAAL Conference in Montreal. And it was a colloquium organized by Vaidehi Ramanathan. The connection was that Vaidehi and I (MORGAN, RAMANATHAN, 2005) had just written a chapter on Critical literacies: local and global issues and practices. It was 2005, and it was an interesting time for critical literacies and critical thinking. It was also in the Annual Review of Applied Linguistics (ARAL), so it probably had stronger readership amongst people interested in critical literacies. Around that same time, I think Lynn Mario was supposed to be on that panel, or I met him at the conference, and I was really interested in his research about the Kashinawá in Amazônia and his perspective on multimodality, on indigenous multimodality that he was doing. I think I even contacted him, maybe in 2007 or 2008 to say: "Do you have actual colour slides of the Kashinawá images that you show in your book?". He wrote a chapter in a really interesting book on local language policies edited by Canagarajah (2004), and the images were fascinating examples of multimodality - and not only multimodality - in the sense that it was also about translanguaging because of the semiotics of the Kashinawá meaning making along with Portuguese. Fabulous article, still one of the favourite things that I've read in this area. The article was used in my class, and students presented it. Then, I asked for the actual images in colour, because the colours themselves are meaningful as I think they emulate or reflect the Anaconda patterning and the meaningful colours of the village of the Kashinawá in their contact with their Portuguese teachers (MENEZES DE SOUZA, 2004). Lynn told me: "Yes, I will send them to you, but you have to promise me to keep in mind the ethics of circulation, which is very important to the Kashinawá". I said: "Yes, we will be very sensitive and will only be circulating them to the students presenting".

Much to my surprise, in 2010 Lynn Mario asked me to come down for three days to the 2nd Seminar of the Novos Letramentos meeting (Figure 1, USP, 2010). 
This initial contact shaped the direction of the subsequent transnational work I would do in Brazil and with Brazilian colleagues. The critical literacies article in ARAL was in part a survey of the topic area, but typical of the survey genre, also attempted to outline future priorities and directions in the research area. One of the interesting aspects of the article begins by foregrounding the idea of reading yourself and "distancing yourself" from dominant discourses and ideologies as foundational to critical literacy work. Informed by poststructuralism, this point makes (self) reflection or interrogation of the historical, discursive conditioning of the subject as a key dimension of meaning making around texts. Vaidehi and I got the idea from an important chapter on criticality written by Allan Luke (2004). We chose the quote below to introduce and frame our ARAL article (Figure 2). I also used it early on in my workshop at USP. After presenting the quote from Luke, I had participants, in groups, interpret Luke's quote and discuss it's curricular and pedagogical implications. After that activity, I showed a slide (Figure 3) with my own interpretation of Luke.

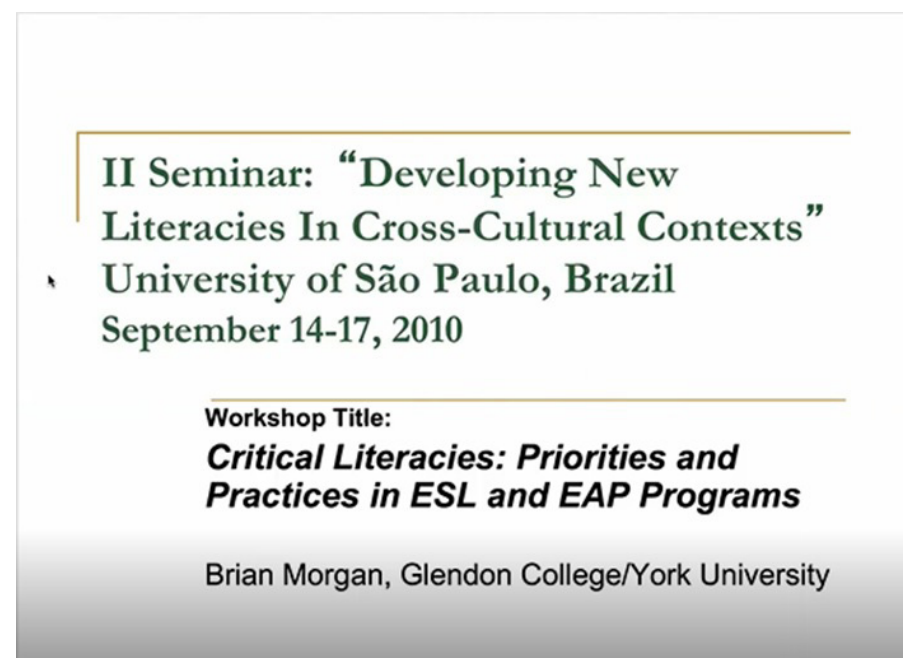

(Figure 1. Morgan, 2010, Seminar, Brazil) 


\section{“To be critical..."}

\section{A useful quote from Allan Luke:}

- To be critical is to call up for scrutiny, whether through embodied action or discourse practice, the rules of exchange within a social field. To do so requires an analytic move to self-position oneself as Other even in a market or field that might not necessarily construe or structurally position one as Other.... This doubling and positioning of the self from dominant text and discourse can be cognate, analytic, expository, and hypothetical, and it can, indeed, be already lived, narrated, embodied, and experienced" (Luke, 2004: 26)

(Figure 2. quote from Luke, 2004; cited in Morgan \& Ramanathan, 2005)

\section{My interpretation of Luke...}

- To be critical, following Luke, is to take up a notion of agency that is both introspective and action-oriented in that social transformation (in schools, communities, or nation-states) requires critical self-reflection. In order to "read the word and the world" (cf. Freire) we must also read ourselves and distance ourselves from common sense beliefs and language practices that sustain social injustices. This "distancing" can and must utilize diverse techniques and text-types-a reflection of the different ways that individuals experience and are subjected to "common sense" (i.e., dominant social and academic discourses). The need for diversity is also a reflection of a complex world increasingly shaped by the logic of images, multimedia and hypermedia (the Internet). Though "distancing" can be accomplished in many ways, there are no guarantees or fail-proof methods to follow. In this respect, critical literacies create space for the agency of others. They do not determine if or how that agency will be realized.

(Figure 3. Morgan, 2010)

So, this was the pedagogical beginning of my Brazil experience. It turned out to be a very busy and intense visit. I had three days of workshops and a few other guest lectures thrown into the mix. Ruberval (Maciel of UEMS) and I always laugh about the "Brazilian vampires" making me work so hard (laughs) when I come for a visit. I now put that out rhetorically - "Is this going to be a vampire visit?"- to get 
people to ease up a bit on my schedule. But to be fair, I still seem to have a lot of fun when I'm in Brazil.

Getting back to my first workshop, it's very interesting how Luke talks about this idea of needing to self-position oneself as Other and utilizing a variety of "tools" or a pedagogical tool-kit that includes cognitive, textual and semiotic variety (i.e., analytic, expository, narrated, embodied and experienced). So, there is not a one-size-fits-all methodology or curriculum for critical work and the literacy task of questioning yourself and your own discursive positioning. There are instead historically situated and contingent possibilities and options.

DF: I think this idea goes back to Michel Foucault as well, because Foucault philosophically speaking - was talking about this scrutiny and this positioning, always insisting on the position of the self, and I think that we have forgotten this along the way, because of the "scientification" of Humanities and of the kind of research we do...

BM: And I would say that even his later work on ethics in The Care of the Self (FOUCAULT, 1988) is relevant because there are important teaching questions there such as: What are the texts that allow ourselves to construct ourselves as ethical subjects/teachers? What do we work with? What kinds of technologies of the self allows us to be ethical subjects at a particular time and place? It had these four components of an ethical self. What is our final view or destination (i.e., telos)? What are the dominant texts that are shaping us? And what are the ones we can work with? So, you can see this curricular thing. What are the texts we give people to allow them to become the kinds of teachers they would feel comfortable being? This is interesting, this is back in 2004 (i.e. the Luke quote on criticality) when poststructuralism was especially prominent amongst critical applied linguists. The other reason why I find this interesting is that Allan Luke (2013) about a decade later goes on to say it's not enough... That the reflexive critical work of understanding yourself, this idea of reflexivity and hyper-reflexivity - in some ways - can be a problem and I would argue that it can be even a bigger problem in teaching.

\section{DF: Why do you think so?}

BM: Well, it's interesting you mentioned Foucault. I mean, in the chapter that Chun and I did (CHUN; MORGAN, 2019), and I think also in the chapter I wrote for you, we have to think about the kind of location... in another question you talk about the locus of enunciation. I find the locus of enunciation for applied linguists 
and language teachers is - due to this kind of writing - the University. And it is a university environment in which we are kind of the lowest of the hierarchy of prestige disciplines. It was funny yesterday at your talk that both Eve (Haque) and Saskia (van Viegen) were complaining about these kinds of problems where the university would be quite happy not having any researchers that are English language teachers: "Just make all those positions simply lecture positions where there is a minimal amount of research"; it is almost like a Bolsonaro scenario where "we don't need that kind of theory, it's not necessary".

\section{DF: Okay, for obvious reasons for them...}

BM: That's right! The discourses are: "We can get language teachers much cheaper". "What kind of research are they doing?" "No, we need researchers that - in the Brazil case - will make us money: research in engineering, research in science, math and technology. That's what we need. That's 'real' research". In the North American universities, you can almost see a case where if you look at the transdisciplinary movement - and I think I did write this in your chapter (FERRAZ; KAWACHI, 2019, in press) - we will see Brazilians quoting Foucault, we will see them quoting Sousa Santos, Walter Mignolo; we - as language teachers - will be very busy researching on and talking about postcolonialism, cultural studies, philosophy, Rancière, Foucault, and Bakhtin, but do you think anyone in Brazil in philosophy is actually reading Lynn Mario Menezes de Souza? What do you think?

DF: I don't think so. Maybe I could refrain that. I think that especially within the group of Projeto de Novos Letramentos (USP, 2009-2015) definitely yes.

BM: I mean, people in philosophy: Will there be someone studying philosophy at USP or any other university in Brazil reading Walkyria Monte Mór? In cultural studies, will there anyone in cultural studies doing postcolonial studies reading Walkyria? We have the same problem in Canada. Critical linguists will be reading Foucault, Rancière, Bakhtin, but will people in literary studies be reading Pennycook? No. There is an interesting story there: It is a one-directional disciplinary relationship that is going on. And here is what happens: What become theoretical priorities in one discipline (philosophy, for example) are maybe priorities that are not necessarily beneficial to the challenges and practicalities of the language teacher.

DF: This refers to our question about language education. In Morgan and Mattos (2018, p. 218), corroborating Monte Mór, you mentioned a key tension or a 
contradiction in relation to language education in Brazil: "a core task of critical work involves challenging existing practices and habits of thought. Yet, this goal is often voiced in texts and discourses in ways that reproduce rather than transform academic and societal power relations, especially in respect to professional hierarchies that distance theorists from practitioners less familiar with privileged forms of meaning making (i.e., academic text production). Monte Mór's point reminds us that, if we want critical work to be locally relevant, we should be open to exploring new and varied ways of talking about it and understanding it through the embodied experiences of students and community stakeholders, a perspective that is indebted to the work of Paulo Freire". Talking about this distance between theorists and practitioners, do you think this is connected to the difficult challenge of trying to break the barriers between university and elementary schools?, meaning that one is not dialoguing with the other because in some ways these teachers are looking for more practical things, and perhaps the insistence on philosophies and theories from teacher educators, or the ways we have been translating theories to them. At least in my perspective this is essential, but I would never ask a public school teacher to read Foucault on the first class. You would have to find ways to imbue philosophy there ...

BM: But here is what I think in relation to my personal experience of the problem. There are two things there: there is an insecurity about the value of research from applied linguists and language teacher educators... I'm going off in trajectories, but one related anecdote was when Stephanie Vandrick and I (MORGAN, VANDRICK, 2009) wrote a chapter on peace education studies and asked: What do we bring to the table? She and I went to this conference in the Bronx, New York, on Peace Studies which encompassed a variety of disciplines. When people saw the title of the presentation "What does second language education contribute to peace studies?" they didnıt care! Who cares what second language education has to say? Very interesting but of course they assumed: "Of course they will want to know what theorists in peace studies have to say", "because our research is much more valuable than your research!".

So, again there is this insecurity to say: "No, we have aspects of our work that are unique and important for you in a genuine dialogic transdisciplinary way to reconsider". I mean, in the North American university, Stephanie and I (Ibid.) - in our article - talk about the fact that we understand texts and language in ways that peace studies people don't understand. We also work in North America in many teaching contexts and also in Brazilian contexts where you have Refugees from different backgrounds that non-teachers will never personally have contact with 
in ways not mediated by dominant media. For example, I would have a classroom where historical enemies sitting in the same room, like an Iraqi and an Iranian, who have never seen or talked to each other, or a Serb and a Croat, who never talked to each other, except through the filtering lens of the dominant media.

The classrooms of language teaching really are unique spaces and we tend again to think that they cannot be theoretically rich, that they cannot contribute to other disciplines, and then Stephanie and I had all these points about how second language education potentially contributes to other disciplines, in this case, peace studies.

This is a real problem. I think language educators like Menezes de Souza and Monte Mór should be read and explored in postcolonial studies. What is in postcolonialism if not teaching applied linguistics from a southern or subaltern perspective? What does it actually look like at the ground level? Because we don't take our own pedagogy seriously, we don't see its uniqueness in speaking to other disciplines that we borrow from. That is one of my concerns when I came to Brazil. We would go to all these seminars, we would sit through meetings, we would read very dense theory, and no one ever said how does this or how has this been realized or actualized in a lesson? In a language policy document? In a curricular innovation? In fact, when I suggested that, sometimes I was told that this is not what we do: "that's pedagogy, we don't do pedagogy". And the argument was that pedagogy is an imposition, it is a modernist imposition that crushes or controls, and manages the local creativity of the individual.

DF: But then if you go further so is the nation-state, so is modern society...

BM: That's right. Here's an interesting argument. When I listened to you, it reminded me of this. The idea of Allan Luke's quote above: the doubling, re-positioning, poststructuralism, Foucault, Derrida, Deleuze and the idea of nomadology; all of these are trying to rupture, pluralize and deconstruct the kind of certainty or humanist certainty of the subject. That is why critical literacies say it is absolutely essential to read yourself, to understand how you have been positioned, and how you are a subject of discourse, and this becomes incredibly important. But here's an interesting question that I think about: In one field or one discipline - because we are always borrowing from philosophy and cultural studies - what is productive doubt? What is epistemic scepticism or productive epistemic scepticism? Questioning knowledge in one discipline: To what extent is that also productive in another discipline? Particularly the preparation of teachers? This is key. 
This is where the transdisciplinary unbalance where we don't value ourselves or we are always borrowing and not giving to philosophy or cultural studies or colonial studies. We are always taking; they never read us. So, to what extent is Deleuzean nomadology and rhizomatic thinking, or Rancière's notion of dissensus, Foucault's questioning of the self, Derrida's deconstructive impulse, and the epistemicide of Sousa Santos productive? These are beneficial, but they are also potentially dangerous, in that they produce doubt that is no longer productive doubt, for it is doubt that can be destabilizing. This is something that actually Norton and I (NORTON; MORGAN, 2013) mentioned in our chapter on poststructuralism. The backlash against poststructuralism has been related to the idea of bringing back a real world, and it is funny because that's exactly where Luke was in this really nice book from 2013. He is basically saying that: "unpacking the relationship between discourse representation and reality remains the core questions of critical literacy as theory and practice" (LUKE, 2013, p. 146), that we need to look at real practices and reality, material things in the world. It cannot be just critical reflection.

DF: I do agree with you. I think I have two points here: the first one is that I totally agree with you and with this idea that we are focused on theory and reflection, even though I do think this is important because without this philosophical background we cannot go further, we cannot question the status quo. The whole history of language education in Brazil for example has been completely structuralist, completely vocabulary-focused, mainly non-contextual. I have the impression it has been like this. This is how I learned English when I was a child. Also, I do not think that projects such as the ones you mentioned could represent language education in the country. What I'm trying to say is that even if some of us are doing this little bit of theorization it is still "a drop in the ocean", for example, the universities which belong to the Projeto Nacional, in my view, are still 30 universities out of thousands of universities (2.407 universities) doing language education based upon literacies.

BM: (...) I think we need to be better as teachers. We need to be able to provide a rationale. Maybe even before we start we preface: "I'm going to try to do something you may not be comfortable with, but I will explain that there is a real strong meaning making reason, an interesting Theory". So, we negotiate instead of getting people to do things - especially teachers - because teachers like to know there is some purpose, a pedagogical, curricular purpose behind that, which gets back to grammar. Here is my critique about grammar. 
I have often heard this said at Brazilian meetings for the reasons you said the structuralist approach to vocabulary and grammar teaching, even pronunciation, that: "Well, we would like to do critical work, but we don't have time. We have to teach some grammar". There is always this idea that these are separate ideas, that methodologically, ideologically you can't teach vocabulary at lower levels, you can't teach grammar structures or pronunciation in any ways that could be called critical, and again I think this problem relates to us not understanding or theorizing our own field, that we are borrowing from other disciplines, to say what's critical.

Hilary Janks' work is full of examples of how even at lower levels you can be doing grammar, vocabulary with interesting perspectives on language and power, even at lower levels. Those were my very first publications: teaching intonation, teaching pronunciation, looking at issues of gender and power in the classroom. And in the same book where I mentioned the Luke chapter (LUKE, 2004), I have got a whole chapter on teaching grammar from a critical perspective (MORGAN, 2004). You mentioned one of my favourite articles, the chapter is there too. Pennycook's (2004) praxicum, the critical moment, it's based on a grammar item: turn off the tap, or close the tap! It starts as a structuralist grammar lesson, but becomes much more. Chun's (2015) work is brilliant in relation to this. So, getting back to language teacher education, letting teachers know that it is not a choice, you don't have to choose "will I be critical, or will I be practical?". It is looking for places where they can come together.

DF: This is a challenge that Orientações Curriculares para o Ensino Médio (BRASIL, 2006) insisted on, this idea of putting these perspectives together is the challenge in relation to language education for the next decades in Brazil...

BM: Yes, it is. And especially with a very hostile government, learning activities that allow for a little bit of wiggle room that you mentioned, activities that may appear to be very neutral and conforming, but they have space for a critical potential. I think that's the key, that's another question, I'm like swimming over the questions...

DF: Still thinking about contextualization, you mentioned in Monte Mór and Morgan (2014, p. 18) that your work - in regards to criticality and citizenship - began in the 1990's, when you taught English as a Second Language in government-funded adult ESL programs in Toronto, a city that according to you is "one of the most racially and ethnically diverse cities in the world, and the most popular destination for newcomers to Canada". Within this context, your "emerging critical awareness" arose through concerns over "infantilizing content 
and passive citizenship practices that aligned with government policies and curricula such as the Language Instruction for New Canadians (LINC) program and the Canadian Language Benchmarks from which LINC is organized". After almost 30 years, what has changed in terms of language education and language policy in Canada? Is it still possible to encounter "infantilizing content and passive citizenship practices" aligned with governmental (traditionalist) decisions? What can you tell us about language education in Canada today?

BM: I think there are still elements of infantilization, but the biggest problem now I think is the shift in Canadian language policy for second-language learners... it is more of the economic and often called the neoliberal orientation. So, where my earliest research was looking at issues in integration and intercultural awareness, and multicultural-intercultural relations and citizenship, the new orientation has been more towards market-based needs and economic issues.

You mentioned nation-state influences. The nation-state notion of multiculturalism was initially one of diversity enriching identity, that we are a multicultural society and the integration of the other has both human rights, ethics and nation-state identity benefits, that we are a diverse welcoming nation. Multiculturalism under more conservative governments started to shift towards calling it an economic asset in a globalizing world order as economics became more global; the notion that we are multicultural, that we have the world inside Canada means that we have assets to compete globally. We have the insider experience of diversity that allows us to be globally competitive. I'm not going into that argument in great length, for example, if that is a reasonable assumption, because the "globalized" world of business, in many ways, may be its own kind of monolithic, capitalist culture, so it's hard to say if there's any substantive diversity in there... that's another off-topic conversation!

What happened in Canada is that curricular documents and just the lives of teachers increasingly became shaped by economic and neoliberal agendas, both in the lack of security for teachers themselves, but also in a growing backlash against spending public money on language teaching, because it's paid through your taxes. The idea that language instruction was designed to help newcomers integrate, to become good citizens and good neighbours was less seen as a "good investment" of public funds. Instead, a rationale based on economic necessity and economic benefit from second/additional language teaching was promoted ... the human capital argument: we need to nurture and facilitate human capital. 
DF: And what happens to plurilingualism? Is English still the main language to be taught? What happens to the other languages? Because as you promote yourself as multicultural, are you moving towards a monolingual orientation, or is it the other way round? Because in both cases you could get money, you could profit, but how is this relationship in terms of policies and how does this reverberate in the practical lives of teachers?

BM: Yes, the plurilingual orientation that could be utilized to make curricula more meaningful - especially at lower levels - this is something that Douglas Fleming and I (FLEMING; MORGAN, 2011) wrote about in a couple of articles and chapters; that ideologies of monolingual instruction and maximum exposure in the target language - and there you see tradition - really contributed to infantilizing adult students because everybody would say: "Even in official curricular documents, we'd like to talk about more serious things, but students' English isn't good enough", "If they could speak better English, we could have meaningful conversations about Canadian Society".

The reality in Toronto is that you can live in Toronto as you can in any major global city and not really know very much English. So, you walked around Toronto and you've seen in the neighbourhoods. I was teaching in Chinatown and had students who would travel one or two hours on public transit from all over the city to come to my Community Centre. Why? Because it was identity, they just loved being in the Chinese Community Centre. And they were lower-level classes, and I would say: "Okay let's do visiting the doctor", and they would go like: "Brian, visiting the doctor! Why would I study that in English?". "Okay, so let's go shopping", "Shopping? Why would I even learn that?", "Banking? In my bank they speak Chinese! Are you kidding?". But they were there every day, interested to learn. To be fair, there were a lot of senior students and for them their interests were to learn more about Canadian society and citizenship. They wanted to know more about the life their kids were going to have and their grandkids were going to have. There were still people that definitely needed to learn to how to go to the bank in English - I'm not saying that we don't teach that - but the problem is that the nation-state has constructed a notion of a common-set of curricular measures and goals, that learning English in downtown Toronto might be the same as learning in rural Manitoba. And that's a huge mistake.

What would often happen is that the monitoring and the policing of funding was through outside supervisors coming in and saying: "This is level 2; you should be teaching them this and this", and students might not be willing to study that for local reasons and they leave. You see this market-driven kind of neoliberal way of 
running a program: "You have to have $\mathrm{X}$ number of bodies in the classroom or the classes close".

It was a challenge to teach, you had mixed levels, and so these were some of the challenges that official curricula did not acknowledge. There was no place in official curricula for any kind of tasks that allowed for or encouraged first languages in the teaching of second/additional ones. Definitely not at an advanced level.

One of the first articles (MORGAN, 2002) that I wrote after finishing my doctorate was this one about an ESL community, and I talk about an activity where the students are using their first language bilingual dictionaries, and this was an advanced class. This was the day after the Quebec government had tabled the wording of a referendum question, and even many Canadians in English didn't quite understand what the question was. But for the students from China and Asia, they wanted to know about the controversy: what does the word sovereignty (in the referendum question) mean compared to independence? So, the whole activity was this: let's get all your dictionaries and compare meanings and debate them, and what their implications are. This kind of work, you would conventionally be told "Oh, you can't use a traditional bilingual dictionary". "That is only for low remedial levels of language instruction, not advanced". But they were having a wonderful time, and I had taught in China for a year, and students loved to do this kind of bottom-up literacy activity where they carefully looked at each word in breaking down the text, like breaking down the word instead of going to a holistic meaning of the text; let's get to each word - not all Chinese students - but when you learn how to be literate in Chinese, if you've ever seen the characters, it's a real focused, disciplined approach to writing characters in Chinese, so there's an orientation to text and word formation that I tried to utilize in the L2 activity.

I wrote this article as part of my dissertation, of paying attention to Chinese L1 vocabulary learning and making that a part of second language instruction from a critical perspective. That was this idea again "you can do vocabulary", but this assumption that across the whole board "never use a bilingual dictionary". Why not? In the class during the activity, everyone was excited and would compare: "What is your dictionary saying?" And they would debate: "Oh, no!", and I would say: "Say it in Chinese, go ahead, use Cantonese", "Write it on the board", "Why is your meaning not matching with the Quebec government's understanding of what the word is?", "What are the connotations and the implications?" So, they loved it; they loved the activity, and these were advanced students, they weren't in a basic level class, and again, in the ideology of language teacher education: "Oh no, you can't do that". 
DF: I think this is the idea of literacy, you need to teach vocabulary but the way you are doing it makes a difference.

Going on... regarding the neoliberal, neoconservative and neofascist times we (Brazilians and some many other people in the world) have faced, not only after the recent presidential elections results, but also in Michel Temer's presidency, how do you think transnational research projects help us understand what is happening in Brazil, in the USA, Canada, and in some countries in Europe)? Or do you have any advice on how to deal with so many frustrations and drawbacks in relation to politics and education?

And I think it connects to another question because I really don't think we discuss neoliberalism in the classrooms and social differences at least in many of the contexts that I know in Brazil. Do you think we should include these conversations in our classes?

BM: Well, it's a really good question. Going back to something you said earlier about the locus of enunciation, if I went to a class of language teachers and talked about neoliberalism it would be a very confusing term for some of them. For one, in North America liberalism actually has a modern association with left-wing especially in the United States - of progressive left-wing and state interventionism, where it has got nothing to do with the laissez-faire liberalism of the 18th century in England, of John Stuart Mill and David Ricardo.

The idea of neoliberalism, if it is to be introduced in a classroom, needs to be carefully contextualized: Neo to what? It comes down to who the audience is? If they are graduate students you can certainly introduce the term, but you would have to get some historical context. However, they certainly can understand the obsession with economic measures, and I think 'class' is also a term that can be contextualized.

These are the questions: What do these terms mean? How can we make them accessible and relevant for a particular audience? How do they relate to our own practices in our universities and teaching? I mean that's the key: Can we make theory lived? How is it embodied in our world and in our lives? And that's the key challenge. How do we make these ideas relevant to our domains of activity and the capacity of being agents of change? So your question then is: What are the possibilities to act under these new kinds of repressive regimes? It's a tough question.

I've been interested in classroom activities that have a kind of a productive ambiguity to them. I did a presentation recently at a conference of the International Society for Language Studies (Waterloo, June 2018). I was looking at critical teaching 
in post-democratic times such as the ones that seem emergent in many countries these days. I've been very interested in the types of projects or assignments that have enough ambiguity that they can be seen as beneficial to conservatives and liberals and radicals alike, the kind of productive ambiguity that allows for a critical dimension to be strategically integrated. As an example, one really effective project that I've been doing in my first-year university class, and I talked about it in an article I co-wrote with Walkyria (MONTE MÓR; MORGAN, 2014), is the Get involved project, which attempts to encourage EAP/ESL students to see themselves as critical ethnographers.

There is a whole area in education called Service Learning. Social conservatives (and autocrats!) see this as instilling a form of patriotic responsibility; they even make it mandatory; it is like doing compulsory military service, service learning! In Ontario, every kid that graduates from high school must have like 40 hours of community volunteering. In this assignment, the language learning component is three-fold: They have to make a group oral presentation for about 20 minutes to half hour; they have to do research on the NGO (non-governmental organization) they have chosen, so they have to be able to access Library resources and read/skim both academic texts as well as on-line non-academic resources; a final language component is a written response paper.

The primary idea of the assignment is that they research a community agency/NGO doing local and/or international development. Now, why there is a productive ambiguity is that, again, governments promote service learning for various reasons; for one, they may officially state they are encouraging dutiful, responsible citizenship. Yet, from a liberal or socialist perspective, they are acting in contradictory, irresponsible ways; one might claim that service learning underpins neoliberal agendas (i.e., ideologies of self-reliance and individual responsibility)that is, volunteering can make up for the lack of government support in a society. So, an infrastructure of NGO's providing food banks and shelters, reduces pressure to provide adequate public services or to increase taxes on the rich.

Where the assignment "wiggle room" gets in, is that you build into the assignment a critical ethnography dimension: have students compare their assignment NGO (and its issue/focus) with one in their own country or one they have read about before. Then bring in a few articles that problem pose the efficacy of development work from a critical and/or post-colonial perspective as part of the reading assignment. Suddenly you are asking them to question, and suddenly you are building into the assignment actions such as: "Do not take the company organization - the NGO - at face value". You pose questions, asking them: Why 
are there too many organizations doing the same thing? How much of the donation money or percentage of donations actually goes to the charity work? And students go visit them. We've had fabulous visits from students to organizations doing indigenous work, doing work with with immigrant/refugee settlement, food things, environmental things. I give them a list of about a hundred possibilities and one of the categories is on gender identity, organizations doing work with LGBT and trans youth. So, you don't have to say to them "you must do this!", but it's there. Ideologically, you just say, "I'm just building responsible citizens, service learning is a 'common-sense' good and often compulsory in some settings".

And there are always going to be a couple of students that are very ideologically conservative, and they are going to pick some organization that the teacher might find disturbing, but you've created wiggle room. You pose questions and let them critique: "Why do these organizations even have to exist?". There is a critical opportunity to reflect on government failure, on the withdrawal of the state under neoliberalism. The critical research component is key; it is not good enough to just go on the internet and repeat what the company or what the NGO says about itself. You must do research from the library about the issue or problem that the agency is trying to address. They get to do analysis and critique of the organization and how it presents itself. They have to make presentations, so this is a chance to go over the genre of oral academic presentations and related elements of L2 pronunciation; the final individual reflective paper has two parts: the first on what they have learned about volunteering in Canada, and the second part is what have they learned about themselves as language learners, what were the problems and challenges of language learning and working in the groups.

Service-learning is again a project-based approach to second/additional learning, and other people have done really good work on students doing critical ethnographies, where they go out - and I use this as one of the readings in this class - a couple of really good young scholars from the United States (MCPHERRON; RANDOLPH, 2013) have this paper on doing critical ethnographies with students, who are obviously new to the context and go out and look at something (i.e., How does a coffee shop organize itself?) from the fresh perspective of the outsider. And sometimes of course it's just too descriptive. There's always a danger of the task becoming exclusively a description rather than analysis, but when you do find analysis and you share this with the class, they go "Wow, look at this perspective!" And, again, if someone says you're doing "Escola com Partido" you say: "You know, I'm helping them to be critical thinkers and that's all good for business", all the 
business schools have critical thinking courses. "I'm teaching them to be good (patriotic!) business people".

You have also opened up an opportunity to look and explore and see some things from a critical perspective. And perhaps this perspective can be transferable to students' lives outside the classroom. I like this project on volunteering and service learning (i.e. critical citizenship) and I do a lot of project-based learning with the teacher education program-the issues analysis projects that I have presented in Brazil (MORGAN, 2016). So, I really like project-based learning; it can be an integration of meaningful content and certain kinds of academic language skills, and then it has a real interesting ideological dimension, a possibility there for critical work.

DF: And what is interesting to me about this project - I know this project from reading and from seeing your presentations - what is interesting to me it is because it answers my questions by stating that you don't necessarily have to come with the word neoliberalism, you're doing it from the other way around, you are asking them to go to businesses and to NGOs, and of course it is embedded; the concept of neoliberalism is embedded because society is pretty much based on economy. You are just asking them to be critical and come up with their own critique on the system.

BM: And I might even dare say that it's a very Freirean idea. You find the limit situations and people themselves discover them in their own lives-reading the word and the world! Then they'll find the words that enrich their understanding of their experience so beginning with experience and moving to the language of understanding and possibly transforming that experience.

DF: You mentioned in Monte Mór and Morgan (2014) that "collaborative projects, in which transnational and international insights are generated, are also important opportunities to re-examine locality at both the institutional and nation-state level; that is, through transnational dialogue, we are better able to appreciate the sociohistorical factors that have uniquely conditioned the roles and responsibilities each of us associates with the notion of active citizenship; similarly, our ongoing collaboration has helped us understand the specific institutional constraints and opportunities within which each of us must conceptualize and develop critical citizenship literacies. As you participated in the "Brazil-Canada Knowledge Exchange Project: Developing Transnational Literacies" in 2011, and have participated in the Projeto Nacional de Novos Letramentos (USP, 2009-2015, 2016-2019), 
what is your evaluation of the transnational literacies projects developed between Brazil and Canada along these 10 years?

BM: Okay. This comes up a bit in that dialogue that Andrea Mattos and I had (MORGAN, MATTOS, 2018). So, I was a little bit critical of - in our discussion just now - that there wasn't enough pedagogy, and maybe there was too much theory, but then again I started to realize that there are some really important reasons why theory is there, and your point about transnational critical literacies generating new ways to see your own locality that you wouldn't have considered before and through contact in collaboration; this idea of critical literacies must include a critique of the knower in a particular historical moment and site, or an investigation of the knower's, reader's and seer's potential to read and understand in a particular place and time.

I've always found that working with Brazilians or working in these projects (because you mentioned that there are 30 universities out of a 1000 doing critical literacy work) that there were so many things that made me reflect about things that I don't think about or never recognized in my local language teaching. The critical imperative that I saw amongst all the people in Brazil was interesting. Ian Martin and I would comment on this; we would go down to CBLA and other big conferences of Applied Linguistics and 1/2,3/4 of the presentations were talking about critical literacies, Queer Theory, post-colonialism, cultural studies and I was thinking that, if I went to the Canadian Association of Applied Linguistics or TESOL Canada, I'd be lucky if there were $5 \%$ even $2 \%$. It started to make me think why that is?

So, coming to grips with thinking about the kinds of literacies that are tied to, for instance, the history you've had before the time of dictatorship and that experience of dictatorship and why critical theory is so important. Given the history that you have, it is important to question people's common sense because in a way unexamined or "selective" common sense is why the dictatorship is back.

It makes me think about our own common-sense kind of naivety or blind spots in Canada; the worst one is our relationship to indigenous people, still. In a sense we are kind of naïve in Canada; I think Novos Letramentos Project people are much less naive about the way in which the government can be oppressive. Our government is oppressive in ways we don't even recognize, because we don't think it's a problem - especially to indigenous people -; it's really bad. So that's an interesting thing: the transnational literacy developed here is more of an awareness of how language is tied to state, elite and class issues, and how in some ways we are kind of common sensically naïve about it and not prepared to fight back like 
Brazilians. We are kind of very docile. We've had governments which have worked against professional language teaching as a viable career option, and have made it into part-time work, requiring us to be way over-certified for the jobs available, and part of this development is because we've become very passive, we've lost that critical edge to act on and complain.

DF: By this April, these projects will have existed for about ten years; do you think we should fight for these projects to be happening? Because under all the increase of actions and discourses towards the dismantling of public higher education in Brazil now, many of us are very fearful; we don't know what or how we're going to teach in the classroom...

BM: Yes, I know, and it is a real fear that we've never had to deal with in Canada like that. Not to that extent... the Ontario government has tried to suppress a more open approach to teaching gender in primary school, and sexuality issues, but I think that there has been enough of a backlash from teachers and the public that the government has had to backtrack somewhat. But I think the Brazil situation is a little crazier with the military taking leadership roles in universities - that's just scary. Then again, look at your Parliament; look at the way they removed Dilma. So, the parliament in Brazil seems to - I don't know enough about Brazilian politics - maintain the interests of the wealthy classes and the ruling classes, who are more easily or openly supported through parliament then they would be in Canada; also, compared to Canada the Brazilian elite seem to control more of the mainstream media.

DF: I do believe this is something for us to discuss now in April 2019. It's going to be one of the most important conferences because as a group, it is either we get together and help each other to build a net, or we'll try to do something else because we are under the risk of losing our jobs, because of this "indoctrinating" stuff they are accusing us of.

BM: There was a really interesting article recently in the New York Times (BARBARA, 2019) about gender and the new Brazilian minister of women, family and human rights, Damares Alves, and her opposition to what she calls "gender ideologies". It's an opinion piece by a woman from Brazil, and her revulsion to Alves's (and Bolsonaro's) patriarchal discourse in which girls have to be socialized as princesses and boys as princes. It's awful because the girls are expected to wear pink and the boys blue. It begins with a story of how the author (Vanessa Barbara) 
doesn't want to know the sex of her unborn child yet, and then people go: "What? What if you buy the wrong colour!? OMG!".

DF: Yes, it's bizarre! Okay, Mr. Morgan. Thank you so much!

BM: Thank you.

\section{REFERENCES}

APPLE, M. (2004). Creating Difference: Neo-Liberalism, Neo-Conservatism and the Politics of Educational Reform. Educational Policy, vol. 18, issue 12, p. 12-44.

BARBARA, V. (2019, JANUARY 16). I Put My Baby Daughter in Dinosaur Overalls. Am I an Anarchist? Tales of gender blasphemy from deep within the land of princes and princesses. Retrieved from the New York Times [on-line]. https://www.nytimes. com/2019/01/16/opinion/brazil-gender-alves.html

BRASIL (2006). Ministério da Educação, Secretaria de Educação Básica. Orientações curriculares para o ensino médio: linguagens, códigos e suas tecnologias / Secretaria de Educação Básica. v.1, Brasília. 239 p.

CHUN, C. (2015). The discourses of capitalism: Everyday Economics and the Production of Common Sense. London and New York: Routledge.

CHUN, C.; MORGAN, B. (2019). Critical research in English language teaching. Springer Second Handbook of English Language Teaching, in press.

FERRAZ, D. M.; KAWACHI, C. J. (Orgs.). Bate-Papo com educadores linguísticos: Letramentos, Formação docente e Criticidade/ Chatting with language educadors: Literacies, teacher education, and critique. Campinas: Pontes Editores, 2019, in press.

FLEMING, D.; MORGAN, B. (2011). Discordant Anthems: ESL and Critical Citizenship Education. Citizenship Education Research Network (CERN) Collection, p. 1-14.

FOUCAULT, M The History of Sexuality Vol. 3: The Care of the Self by Michel Foucault (1988, Paperback).

LUKE, A. (2004). Two takes on the critical. In B. Norton \& K. Toohey (Eds.), Critical pedagogies and language learning. Cambridge: Cambridge University Press, p. 21-29. 
LUKE, A. (2013). Regrounding critical literacy: Representation, facts and reality. In M. R. Hawkins (Ed.), Framing language and literacies: Socially situated views and perspectives. New York: Routledge, p. 136-148.

McPHERRON, P.; RANDOLPH, P. T. (2013). Thinking like researchers: An ESL project that investigates local communities. TESOL Journal, 4(2), p. 312-331.

MENEZES DE SOUZA, L. M. T. (2004). The Ecology of Writing among the Kashinawa: indigenous multimodality in Brazil. In: CANAGARAJAH,S. (Ed.). Reclaiming the Local in Language Policy and Practice, p. 73-95.

MONTE MÓR, W.; MORGAN, B. (2014). Between conformity and critique. Teaching volunteerism, 'activism' and active citizenship: Dangerous pedagogies? Interfaces Brasil-Canadá [Special Issue], 14 (2), p. 16-35.

MORGAN, B. (2002). Critical practice in community-based ESL programs: A Canadian perspective. Journal of Language, Identity, and Education, 1, p. 141-162.

MORGAN, B. (2004). Modals and memories: A grammar lesson on the Quebec referendum on sovereignty. In B. Norton \& K. Toohey (Eds.), Critical pedagogies and language learning. Cambridge: Cambridge University Press, p. 158-178.

MORGAN, B. (2016). Language teacher identity and the domestication of dissent: An exploratory account. TESOL Quarterly, 50 (3), p. 708-734.

MORGAN, B.; MATTOS, A. (2018). Theories and Practices in Critical Language Teaching: A Dialogic Introduction. Rev. Bras. Linguíst. Apl., v. 18, n. 2, p. 213-226.

MORGAN, B; RAMANATHAN, V. (2005). Critical Literacies and Language Education: Global and Local Perspectives. Annual Review of Applied Linguistics. Issue 25, p. 151-169.

MORGAN, B.; VANDRICK, S. (2009). Imagining a Peace Curriculum: What SecondLanguage Education Brings to the Table. PEACE \& CHANGE, Vol. 34, No. 4, p. 510532, Peace History Society and Peace and Justice Studies Association.

NORTON, B.; MORGAN, B. (2013). Poststructuralism. The Encyclopedia of Applied Linguistics, Edited by Carol A. Chapelle. Blackwell Publishing Ltd, p. 1-6.

PENNYCOOK, A. (2004). Critical moments in a TESOL praxicum. In B. Norton \& K. Toohey (Eds.), Critical pedagogies and language learning. Cambridge: Cambridge University Press, p. 327-345. 
USP. (2009-2015). Projeto nacional de formação de professores: novos letramentos, multiletramentos e línguas. $1^{\circ}$ ciclo. Disponível em: http://projetonovosletramentos. blogspot.com/ Acesso em: 10 janeiro 2019.

USP. (2016-2019). Projeto Nacional de Letramentos: Linguagem, Cultura, Educação e Tecnologia. $2^{\circ}$ Ciclo. Disponível em: http://projetonovosletramentos.blogspot. com/ Acesso em: 10 janeiro 2019.

Recebido: 6/03/2019

Aceito: 18/03/2019

Publicado: 29/03/2019 